\title{
河川景観の特性分析に基づく景観施策及び住民活動に関する一考察 恵庭市漁川に着目して \\ A STUDY ON INITIATIVES AND COMMUNITY INVOLVEMENTS BY ANALYSING CHARACTERISTICS OF RIVERSIDE LANDSCAPES
}

Focus on the Izari river in Eniwa city flowing through a diverse landscape

\author{
山崎嵩 拓*, 坂井 文**
}

Takahiro YAMAZAKI and Aya SAKAI

\begin{abstract}
The purpose of this study is to clarify the characteristics of riverside landscape by focusing on Izari River in Eniwa city flowing through a diverse landscape including forests, urban and agricultural lands. This paper examines methods of improving the riverside landscapes by using landscape measure adopted by plural sections.

Through this study, there are three issues about riverside landscape. 1. The effect of land use plan formulated by several sections is limited. 2. A few administrators concern that their river administration facilities might spoil the scenery. 3. The community activities for maintaining riverside landscape are conducted especially in public spaces.
\end{abstract}

Keywards : Riverside Landscape, Land Use, Landscape Plan, Landscape Elements, Community Activity 河川景観, 土地利用, 景観計画, 景観構成要素, 住民活動

\section{1.はじめに}

\section{$1-1$. 研究の背景}

我が国の河川は一般に、山間部や都市域等、様々な地域を流下し ており、景観整備では河川周辺の土地利用やまちづくりとの連携を 図る事が求められている ${ }^{1)}$ 。特に 1997 年 5 月の河川法改正により「環 境」が管理目的に追加され、更に「景観、人と河川との豊かな触れ 合いの確保等を総合的に考慮」した河川整備計画の策定義務から、 河川景観に関する取組みが進められている。一方で 2012 年 5 月に北 海道が水源地の保全に関する条例を制定してから、全国の広域自治 体で土地の権利移転に届出を求める取組みが進められている注1)。こ れに伴い森林法では、所有者変更時に届出を義務付ける改正を進め る等、河川周辺では適正な土地利用が目指されている。

他方で「都市のみならず、農山漁村、自然公園の区域等における 良好な景観の促進」を目的とした景観法が施行して 10 年が経過した。 景観法を活用する上で義務付けられている景観計画の策定が全国で 進められており、計画の 9 割以上が行政区域全域を計画区域に設定 する事で、土地利用を問わず包括的な景観行政を目指している注2)。 また景観法では「道路や河川等の公共施設の整備は、地域の良好な 景観の形成の取組みとの調和を図るという観点から」景観重要公共 施設制度を設けている ${ }^{2)}$ 。つまり、周辺に複数の土地利用を有寸る公 共施設を中心とした景観形成では、関係する行政施策を考慮して進
める必要がある。

河川景観に関する研究として、村川ら ${ }^{3)}$ は河川景観の評価特性に ついて建造物や護岸が注視される傾向を示し、横山ら ${ }^{4)}$ は河川空間 の眺望景観の視覚特性について象徴的な景観構成要素は距離に関わ らず視線が停留する事を明らかにしている。つまり周辺の土地利用 が河川景観に影響を与えている一方で、沿川の行政施策について景 観の観点から分析した研究はみられない。景観と土地利用に関寸る 施策を対象とした研究として、木野ら ${ }^{5)}$ は都市計画区域外等の規制 が緩い区域における景観法を活用した建築物の形態規制が、土地利 用コントロールの手法として有効である事を示している。小林 ${ }^{6)}$ は 農村自治体における景観計画の策定過程及び内容の整理を通じ、区 分ごとの目標に応じた規制の適用では、景観計画以外の関連計画と の整合性が図られていない事を示している。景観計画が土地利用を 包含した視点を持ち運用できる可能性が示されている一方で、複数 の土地利用に着目し、現行の各種計画や事業等の行政施策を含めて 分析した研究はみられない。

\section{1-2. 研究の目的及び方法}

そこで本研究は、沿川に複数の土地利用を有する河川景観の特性 と課題について、河川とその周辺の計画・整備・管理に関わる施策 の分析及び現状調查により明らかにし、良好な河川景観形成に資す る方策を考察する事を目的とする。研究対象は全国で初めて水源地
${ }^{*}$ 北海道大学大学院工学院 大学院生 $\cdot$ 工修

** 北海道大学大学院工学研究科 准教授 $\cdot$ Ph.D. 


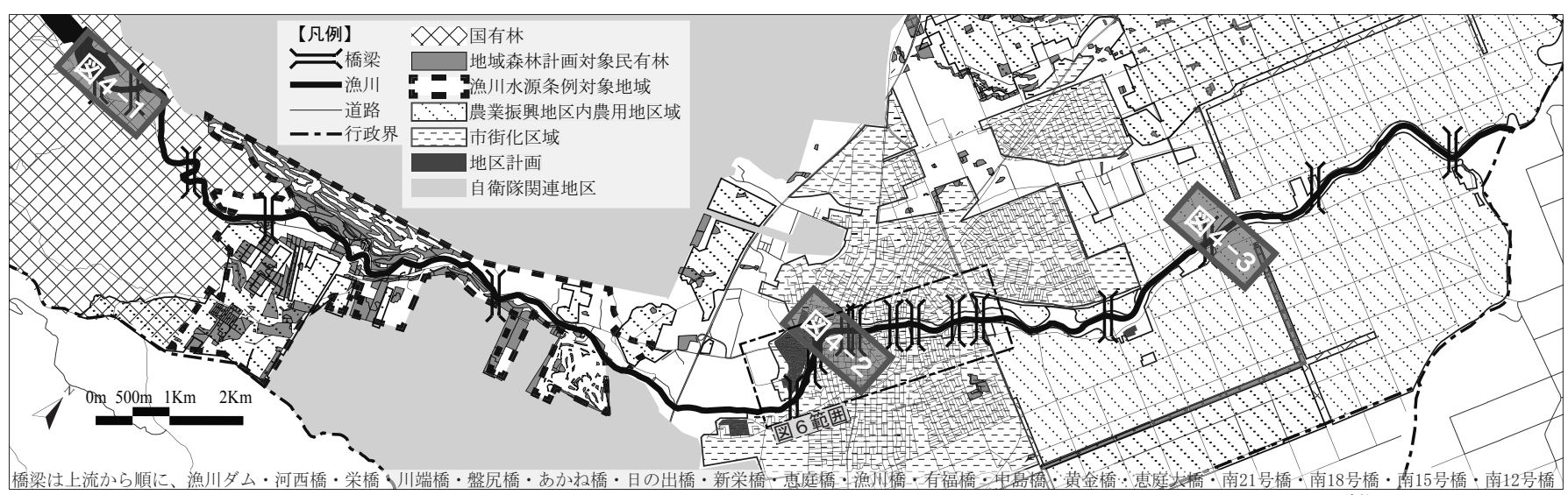

図 1 恵庭市漁川沿川に決定される森林法・都市計画法・農振法及び漁川水源条例に基づく土地利用規制注3

域保全条例を制定した北海道の内、更に 10 年以上先駆けて水源地保 全へ向けた条例を制定する等、河川周辺の適正な土地利用に取組ん でいる恵庭市の漁川とする(図 1 )。恵庭市では 2011 年 3 月策定の「第 4 期恵庭市総合計画・後期基本計画」にて、第一目標として森林・農業・ 都市地域の特性に応じた土地利用を図る事、第二目標として恵庭ら しい景観づくりを掲げている注4)。漁川は西から東に森林・都市・農 業地域を流下し、北海道による地域の良好な景観資源及び主要な展 望地の指定を各地域に受けている事から 注5)、景勝地の機能を有する 河川である（図 2)。また恵庭市景観形成基本計画（以下、景観計画） において、漁川を景観軸と位置付けている他、河川におけるまちづ くりと連携した活発な住民活動が対外的に評価されている注6)。更に 漁川は 2005 年 4 月策定の河川法に基づく石狩川水系千歳川河川整備 計画（以下、河川整備計画）の対象河川であり、流域を占める山間域・ 都市域・農業域と調和寸る河川景観の保全や人工構造物を河川景観 に馴染ませる事などが目指されている。そこで本研究では施策の分 析を、基礎自治体が個別規制法に基づき策定する土地利用に関する 計画、景観を構成する要素ごとの事業・取組み、景観や河川環境の 維持管理に資する住民活動を対象として行った。研究方法は恵庭市

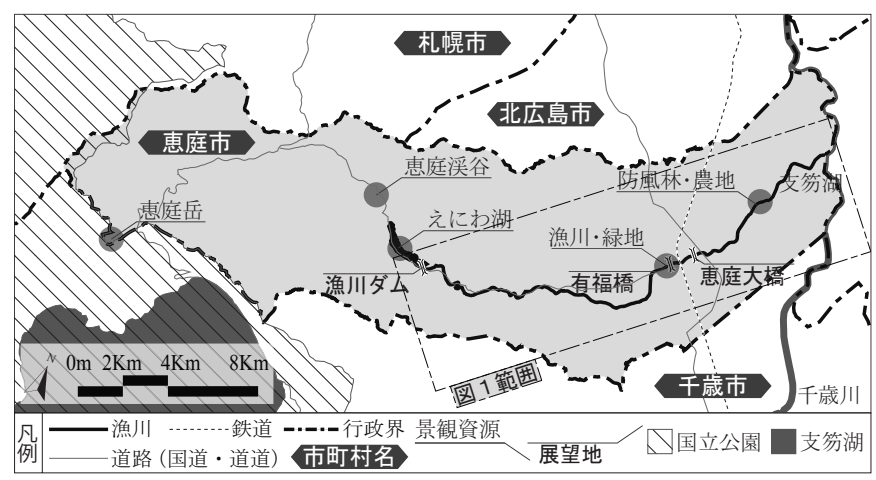

図 2 北海道が指定する地域の良好な景観資源·主要な展望地の立地
の各種計画、議事録等の行政資料・文献調查、現地調查、恵庭市の 各担当課及びダム管理者、住民団体、地元企業へのヒアリングとする。

\section{2. 恵庭市の個別規制法に基づく土地利用に関する計画}

国土利用計画法に基づき区分される森林・都市・農業地域を有す る基礎自治体は基本的に、個別規制法に基づく計画を策定する事が 求められる。そこで次節より、恵庭市が策定した森林整備計画（以下、 森林計画) ・都市計画マスタープラン (以下、都市マス) ・農業振興 計画（以下、農振計画）について景観の視点から分析する（表 1 ）。

\section{$2-1$. 森林整備計画}

恵庭市では、2008 年度から 10 年間を計画期間とする森林計画を策 定し、基本方針として漁川上流域の森林地帯の自然景観を維持・増 進する事などを定めている。森林が持つ機能に応じて計画対象民有 林に区分を設けており、上流域の保健・文化機能等維持林では美的 景観に配慮した施業、防風林に指定される生活環境保安林は景観創 出による生活環境保全等、景観の視点を含めた施業の方針を地域特 性に応じて定めている。

\section{2-2. 都市計画マスタープラン}

恵庭市では今後の都市計画の基本理念と土地利用や景観形成と いった分野別の基本方針を示寸計画として、2011 年度から 10 年間を 計画期間とする都市マスを策定している。漁川や防風保安林を水と 緑の軸と位置付け、多目的なレクリエーションの場として整備する 事や、住宅地の住環境整備等を基本方針としている。望ましい都市 像の実現に向け、地区計画等の土地利用規制により対応する事を計 画の役割としている。具体的には、質の高い良好な住宅地形成や優 良田園住宅の整備時に地区計画を活用寸る事を定めている。

\section{$2-3$. 農業振興計画}

恵庭市では関係者の連携による地域特性を活かした農業の振興を 目的に、2011 年度から 10 年間を計画期間として農振計画を策定して

表 1 個別規制法に基づき策定される土地利用に関する法定計画

\begin{tabular}{|c|c|c|c|}
\hline 計画 & |恵庭市森林整備計画 & 恵庭市都市計画マスタープラン & 第3期恵庭市農業振興計画 \\
\hline 策定年月 & 2008.3 & 2011.3 & 2011.3 \\
\hline 計画期間 & 2008-2017年度 & 2011-2020年度 & 2011-2020年度 \\
\hline 根拠法 & 森林法 & 都市計画法 & 農業振興地域の整備に関する法律(農振法) \\
\hline 目的 & \begin{tabular}{|l} 
水源涵養機能を保全する為無計画な伐採を防止 \\
し、優れた自然景観を貴重な財産として維持増進
\end{tabular} & $\begin{array}{l}\text { 将来の都市像と共に土地利用・都市計画の方針を } \\
\text { 示し、都市づくりの総合的な指標を定める }\end{array}$ & $\begin{array}{l}\text { 地域農業が抱える諸課題を認識し、関係者連携の } \\
\text { 下、地域特性を活かした農業を念頭に策定 }\end{array}$ \\
\hline $\begin{array}{l}\text { 景観にこ } \\
\text { 関わる } \\
\text { 基本方針 }\end{array}$ & \begin{tabular}{|l} 
(1)漁川と渓谷・湖と周辺民有林は水瓶として重要 \\
(2)防風林と周辺民有林は農地·住環境を守る役割 \\
(3)盤尻のゴルフ場や渓谷は文化活動推進上重要 \\
$\rightarrow$ 特性・機能を勘案し、森林の維持を行う区域設定
\end{tabular} & $\begin{array}{l}\text { (1)住宅地では地区計画等により良好な住環境維持 } \\
\text { (2)優良田園住宅は都市・農村の調和した環境整備 } \\
\text { (3)漁川等の河川はレクェーション場として整備 } \\
\text { (4)道の駅周辺は拠点として河川空間と連動し整備 }\end{array}$ & $\begin{array}{l}\text { 1)多様な担い手の育成と確保 } \\
\text { 2)農地の安定的な利用と確保 } \\
\text { 3)生産性の高い土地基盤の確立 } \\
\text { 4)農を中心とした地域活力の創出 }\end{array}$ \\
\hline
\end{tabular}


いる。計画の基本方針として、農を中心とした地域活力の創出へ向 けた継続的な都市農村交流事業の展開等を揭げている。具体的な方 策としては、農村の持つ食糧の生産や緑の景観等、多面的な機能を 市民の財産として位置付け、グリーンツーリズム協議会による活動 の実施や地域協働による農地・水・環境の保全管理等を挙げている。

\section{3．景観計画と土地利用に関する法定計画の対応関係}

2 章により土地利用ごとに策定される法定計画ではそれぞれ特徵が みられた。本章ではこれらの計画と、景観計画に基づく地域区分ご との基本方針の対応関係を分析し、森林計画・都市マス・農振計画 それぞれの特性を明らかにする。先ず次節に、景観計画の概要を示す。

\section{3-1. 景観形成基本計画}

恵庭市は 2008 年 3 月に、水と緑と花に彩られたまちを目標に任意 計画として景観計画を策定した。市域を、漁川上流域を中心とした 自然景観ゾーン、都市地域の住宅地等を中心とした都市景観ゾーン、 その外縁に広がる田園や防風保安林から成る農村景観ゾーンに区分 し、更に漁川をはじめとする河川や幹線道路を景観軸と位置付けて いる（図 3 ）。景観ゾーンごとに景観上の課題を指摘した上で、景観 形成の方針が提示されている。計画の推進方策として、橋梁を更新 する際は漁川景観検討委員会によるデザイン審査を行う事を定める

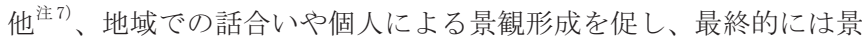
観行政団体への移行を目指寸としている。

\section{3-2. 景観形成基本方針と法定計画の対応関係}

景観計画に示される景観ゾーンごとの景観形成基本方針と、各法 定計画の記述の対応関係を分析し、表 2 にまとめた。

まず、景観ゾーンごとに定められる主要な方針については概ね各 法定計画に類似する記述があり、自然景観ゾーンの渓谷周辺の森林

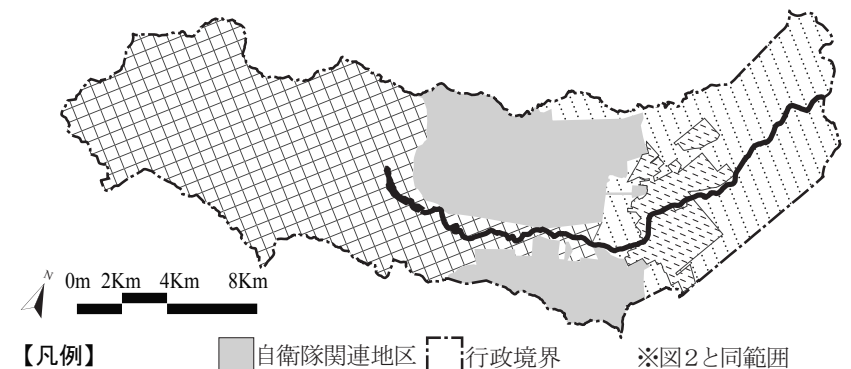

的自然景観ゾーン尽㵔市景観ゾーン農村景観ゾーン— 漁川 (景観軸)

図3 景観計画に基づく地域区分
景観維持や農村景観ゾーンの防風林の維持、農業の振興は、森林計画・ 農振計画の目的に一致しており対応関係にある。続いて建築物の規 模や色彩に関する方針は、全ての景観ゾーンで掲げられている。法 定計画の内、建築物に関する記述を有する都市マスでは、建築物の 誘導にあたり地区計画の決定による住環境向上等を位置付けている。 屋外広告物については各景観ゾーンでサインシステムを組み立てる といった方針を掲げているが、全ての法定計画に含まれない項目で あり、現状は北海道屋外広告物条例に基づく基準が適用されている注 8)。また景観形成へ向けた組織づくり等、行政により主導する事が望 ましい項目では法定計画ごとに異なる対応がとられている。実施す る施策を明記する農振計画では、農地・水・環境保全会の設置といっ た組織づくりを施策の内容に組み込んでいるが、森林計画や都市マ スに具体的な記述はない。

以上より各法定計画における景観に着目した特性として、森林計 画では地域特性に応じた森林の維持管理方法について、区分ごとに 景観の視点を含めて定めている。都市マスでは環境や景観の維持・ 創出へ向けて地区計画等の土地利用規制との連動による開発誘導を 目指している。農振計画では組織的な取組みを担保する仕組みづく りを位置付ける傾向にあるという事が明らかになった。

\section{4. 橋梁を視点場とした河川景観の現状}

計画の分析に続き景観ゾーンごとの河川景観の現状を明らかにす るため、漁川の漁川ダム・千歳川放流口間に架かる橋梁を視点場と し 注9)、上流・下流方向に向かって撮影したパノラマ写真と周辺の土 地利用図を用いて調查を行った(図 4 )。全 36 枚の写真(以下、シーン) の景観構成要素及び土地利用規制の決定状況をまとめた結果を表 3 に示す注 ${ }^{10)}$ 。次節より各景観ゾーンの現状把握として、表 3 の分析と 景観計画に基づく景観上の課題との照らし合わせを行った ${ }^{\text {注11)。 }}$

\section{4-1. 自然景観ゾーンの現状}

自然景観ゾーンには 5 本の橋梁が架かり、1 シーンの平均景観構 成要素数は 3.0 と、他の景観ゾーンの半数以下である。全てのシー ンに森林が含まれ、人工的要素は主にダム管理者により設置される 建築物や工作物が確認される。景観上の課題の内、森林のみが景観 構成要素として抽出され、サインや農業用施設は自然景観ゾーンの 全てのシーンで見られなかった。土地利用規制は上流部に国有林、 下流部の民有林には裸地面積の減少・分散を方針とする水源涵養林 が指定されている。尚、民有林の後背地に広がる自衛隊関連地区は

表 2 景観計画の景観形成基本方針と法定計画の対応関係

\begin{tabular}{|c|c|c|c|c|}
\hline ゾーン & 景観計画における各景観ゾーンの景観形成基本方針 & 恵庭市森林整備計画 & 恵庭市都市計画マスタープラン & 第 3 期恵庭市農業振興計画 \\
\hline \multirow{3}{*}{$\begin{array}{c}\text { 自然景観 } \\
\text { ゾーン }\end{array}$} & $\nabla$ 緑豊かな森林景観や漁川の清流景観を守り育てる事を最重要方針 & 渓谷·湖周辺森林の維持管理 & 自然に人間が寄り添う景観 & \\
\hline & ○ゾーン内施設は位置·規模・形状·色彩等を周囲と調和を図る & & & \\
\hline & ○恵庭渓谷・湖は放置物の撤去やサイン類のデザイン調和を進める & & & \\
\hline \multirow{4}{*}{$\begin{array}{c}\text { 都市景観 } \\
\text { ゾーン }\end{array}$} & V道路·河川緑地·公共空間等が繋がって安全な美しい街並みへ & & 移動連続性を確保する空間 & \\
\hline & ○住宅地では周りに気遣う家づくりや庭·道路の手入れの景観づくり & & 地区計画等による住環境向上 & \\
\hline & ○ノボリや広告・看板の整理、デザイン統一でイメージアップ & & & \\
\hline & 口公園·緑地等を育てて維持管理等に主体的な市民参画を促す & & & \\
\hline \multirow{4}{*}{$\mid \begin{array}{c}\text { 農村景観 } \\
\text { ゾーン }\end{array}$} & 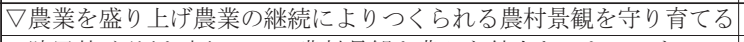 & & & 農地の安定的利用 \\
\hline & ○農家住宅·付帯施設の形状·色彩は建築群で統一を図り農村景観演出 & & 優良田園住宅の建設 & \\
\hline & ○ファームサインやサインシステムを組み立て効果的な設置を進める & & & \\
\hline & 口農道等の管理について住民だけでなく協働で行う仕組みをつくる & & & 農地·水·環境保全委員会設置 \\
\hline \multirow{2}{*}{ 景観軸 } & 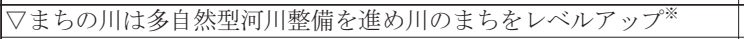 & & 親しまれる水辺環境の保全 & \\
\hline & ا橋梁は形状や色彩等について周辺との調和を図る※* & & & \\
\hline 凡例 & $\nabla:$ V゙ーンごとの主要項目 ○: 建築物に関する項目 & ンに関する項目 & づくりに関する項目 & \\
\hline
\end{tabular}

※) 法定計画との対応関係は限定的であるが、任意計画の「新・水と緑のやすらぎプラン」が河川整備の指針となる事を目的として策定されている

※※）法定計画には記述がないものの、景観計画にて「漁川景観検討委員会」による橋梁の景観検討の取組みを位置づけている 


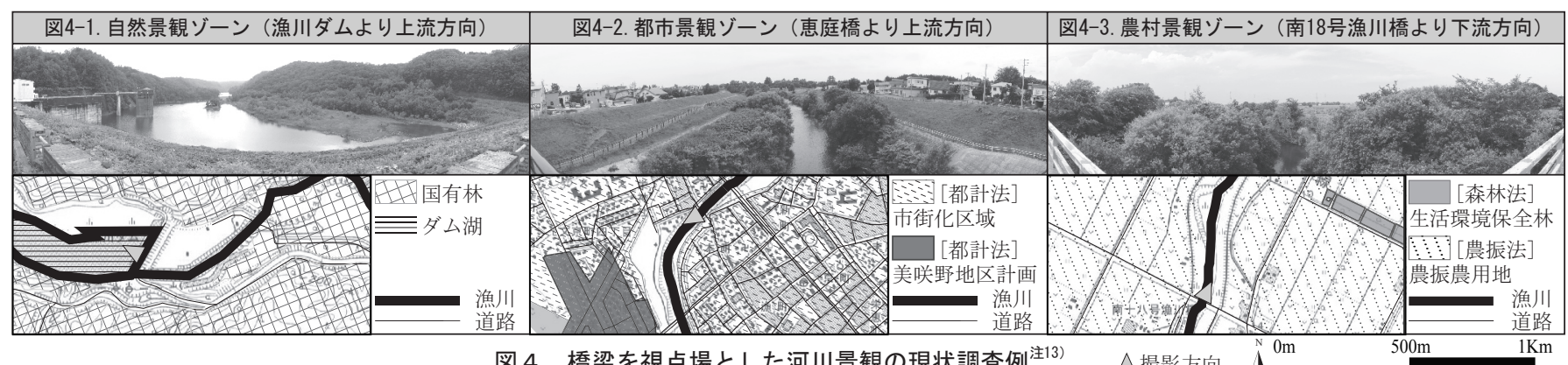

図 4 橋梁を視点場とした河川景観の現状調査例 ${ }^{(i 13)}$

$\triangle$ 撮影方向

表 3 各橋梁を視点場とした景観構成要素及び土地利用規制の決定注14)

\begin{tabular}{|c|c|c|c|c|c|c|c|c|c|c|c|c|c|c|c|c|c|c|c|c|c|c|c|c|}
\hline & \multicolumn{5}{|c|}{ 自然景観ゾーン } & \multicolumn{9}{|c|}{ 都市景観ゾーン } & \multicolumn{4}{|c|}{ 農村景観ゾーン } & \multicolumn{3}{|c|}{ 合計 } & \multirow{3}{*}{$\begin{array}{l}\text { 合 } \\
\text { 計 }\end{array}$} \\
\hline & & & \multirow{2}{*}{$\begin{array}{l}\text { 漁川ダム } \\
\text { 上 下 }\end{array}$} & \multirow{2}{*}{\begin{tabular}{|c|} 
河西橋 \\
上
\end{tabular}} & \multirow{2}{*}{$\begin{array}{l}\text { 栄橋 } \\
\text { 上下 }\end{array}$} & \multirow{2}{*}{$\begin{array}{l}\text { 川端橋 } \\
\text { 上 下 }\end{array}$} & \multirow{2}{*}{\begin{tabular}{|l} 
盤尻橋 \\
上 下
\end{tabular}} & 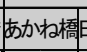 & \multicolumn{2}{|c|}{ 儃の出橋新栄橋 } & \multirow{2}{*}{\begin{tabular}{|l|} 
恵庭橋 \\
上 下 \\
\end{tabular}} & \multirow{2}{*}{$\begin{array}{c}\text { 漁川橋 } \\
\text { 上 下 } \\
\end{array}$} & \multirow{2}{*}{$\begin{array}{l}\text { 有福橋 } \\
\text { 上下 }\end{array}$} & 中島橋 & 黄金橋 & 憲庭大橋 & 南21号橋 & 喃18号橋 & 南15号橋 & 南12号橋 & 自 & 都 & 農 & \\
\hline & & & & & & & & 上下 & 上下 & 上下 & & & & 上下 & 上下 & 上下 & 上下 & 上下 & 上下 & 上下 & & 市 & 村 & \\
\hline & 建 & 建 公営住宅 & & & & & & & 0 & & & 00 & 00 & & O & O & & & & & 0 & 7 & 0 & 7 \\
\hline & 笱 & 沕 公共施設 & (艹) & 0 & & & & & $\mathrm{O}$ & & & & & & 0 & O & $\mathrm{O}$ & & 0 & & 2 & 3 & 2 & 7 \\
\hline & & 柯川管理施設 & 0 & & & & 0 & & 0 & 0 & 0 & & & & 0 & 0 & & & 0 & & 2 & 5 & 1 & 8 \\
\hline & 公 & 人工護岸 & 0 & 0 & & & & 0 & & & 00 & 00 & 00 & 0 & & & 0 & & & & 2 & 8 & 1 & $11 \%$ \\
\hline & 設 & 工他の橋梁 & & & & & & Ö. & O & $0^{2}$ & 0 & $\begin{array}{ll}0^{2} \\
\end{array}$ & $0 \%$ & 0 & $0^{2}$ & 0 & & & & & 0 & 10 & 0 & $10^{\circ}$ \\
\hline & & 物看板 & $E-$ & $=$ & & & & $\theta$ & $=$ & $=0$ & $\theta \theta$ & $\theta-\theta$ & $\theta$ & $=$ & $\theta$ & $\theta \theta$ & & Q & O & & 0 & 11 & 2 & 13 \\
\hline $\begin{array}{l}\text { 人 } \\
\text { 工 }\end{array}$ & & 電線 & & & & 0 & 0 & 0 & & & 0 & & & & & & 0 & & & & 2 & 2 & 1 & 5 \\
\hline 的 & & 鉄塔 & & & & & & & & 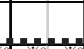 & & 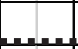 & $\ldots$ & .. & . & ㅇ. & 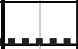 & 인 & 0 & & 0 & 2 & 2. & 4 \\
\hline 要 & & 戸建住宅 & & & & & & 00 & 00 & 00 & 00 & 00 & 00 & 00 & 00 & 0 & 0 & 0 & & & 0 & 17 & 2 & 19 : \\
\hline & 築 & 築 集合住宅 & & & & & & 0 & 0 & 00 & 0 & 00 & 0 & 00 & & & & & & & 0 & 10 & 0 & $10^{\circ}$ \\
\hline & 民物 & その他 & & & & & & & & 0 & 0 & 0 & & & & 00 & & 0 & 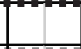 & & 0 & 5 & 1 & 6 \\
\hline & 施— & 農業用施設 & & & & & & & & & & & & & & & $\theta$ & $\theta \theta$ & $\theta-\theta$ & $\theta$ & 0 & 0 & 7 & 7 \\
\hline & 設 $\mid$ I & エビニールハウス & & & & & & & & O & & & & & & & 00 & 0 & & & 0 & 1 & 3 & 4 \\
\hline & & 乍局屋外広告物 & & & & & & 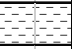 & $\theta$ & 0 & $\theta$ & 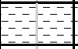 & 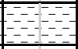 & - & $\theta$ & & 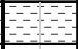 & - & 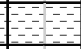 & 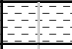 & 0 & 4 & 0 & 4 \\
\hline & & 電波塔 & 0 & & & 0 & & & & & & & & & & & 0 & 0 & 0 & 0 & 2 & 0 & 4 & 6 \\
\hline & & 河川 & 0 & 00 & 00 & 00 & 00 & 00 & 00 & 00 & 00 & 00 & 00 & 00 & 00 & 00 & 00 & 00 & 00 & 00 & 9 & 18 & 8 & 35 \\
\hline & & 農地 & & & & & & & & & & & & & & & 00 & 00 & 00 & 0 & 0 & 0 & 7 & 7 \\
\hline 自 & & 河川緑地 & & & & & & & & 0 & & 0 & & 0 & $\theta 0$ & 00 & & 0 & & & 0 & 7 & 1 & 8 \\
\hline 然 & 緑地 & 也自転車道 & & & & & & 0 & 00 & 00 & 00 & 0 & & & & 00 & 00 & 00 & & & 0 & 10 & 4 & 14 \\
\hline 要 & & 公園 & 0 & & & & & $\theta$ & 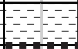 & 0 & 0 & $\theta$ & $\theta$ & & 0 & 00 & & & & & 1 & 9 & 0 & $10^{\circ}$ \\
\hline 素 & & 植林 & & & & & & 0 & & & & & 0 & & & & & & 0 & & 0 & 2 & 1 & 3 \\
\hline & 林地 & 也防風林 & & & & & & & & & & & & & & & 00 & 00 & O" & O & 0 & 0 & 6 & 6 \\
\hline & & 森林 & 00 & 00 & 00 & 0 & 0 - & & & & & & & & & & & & 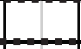 & & & 0 & 0 & 10 \\
\hline & & 小計 & 53 & 42 & 22 & 24 & 42 & $\begin{array}{lll}7 & 7 \\
\end{array}$ & \begin{tabular}{|l|l}
5 & 7 \\
\end{tabular} & $\begin{array}{ll}6 & 10 \\
\end{array}$ & $\begin{array}{|ll|}8 & 9 \\
\end{array}$ & \begin{tabular}{|l|l|}
8 & 9 \\
\end{tabular} & \begin{tabular}{|l|l}
8 & 6 \\
\end{tabular} & 5 & \begin{tabular}{|l|l|}
6 & 8 \\
\end{tabular} & {$\left[\begin{array}{ll}10 & 8\end{array}\right]$} & \begin{tabular}{|l|l}
10 & 7 \\
\end{tabular} & {$\left[\begin{array}{ll}10 & 7\end{array}\right]$} & $\begin{array}{ll}8 & 5 \\
\end{array}$ & 5 & & 平坽 & & 214 \\
\hline & & 合計 & 8 & 6 & 4 & 6 & 6 & 14 & 11 & 16 & 17 & 15 & 12 & 9 & 13 & \begin{tabular}{|l|}
17 \\
\end{tabular} & 17 & 17 & 13 & 6 & 3.0 & 6.9 & 6.6 & \\
\hline 森 & & 国有林 & 00 & 00 & 00 & & & & & & & & & & & & & & & & 6 & 0 & 0 & 6 \\
\hline 林 & \begin{tabular}{l|l} 
保 \\
安
\end{tabular} & 水源涵養林 & & & & 0 & 00 & & & & & & & & & & & & & & 3 & 0 & 0 & 3 \\
\hline 法栟 & 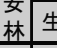 & 生活環境保全林 & & & & & & & & & & & & & & & & 0 & 0 & & 0 & 0 & 2 & 2 \\
\hline & & 近隣商業地域 & & & & & & & & & 0 & 00 & & & & & & & & & 0 & 3 & 0 & 3 \\
\hline & & 市一種住居地域 & & & & & & & & O & & & 0 & 0 & & & & & & & 0 & 3 & 0 & 3 \\
\hline 都素 & & 辕 二種住居地域 & & & & & & & & & O & 0 & & & & & & & & & 0 & 2 & 0 & 2 \\
\hline \begin{tabular}{l|l} 
市 \\
計
\end{tabular} & & 区一種中高住専 & & & & & & $\mathrm{O}$ & 0 & & & & & & & & & & & & 0 & 2 & 0 & 2 \\
\hline 画 & & 二或種中高住専 & & & & & & 00 & 00 & 0 & 0 & 0 & 00 & 00 & 00 & 0 & & & & & 0 & 14 & 0 & 14 \\
\hline 法 & 域 & 一種低住専 & & & & & & & 0 & 00 & & & & & & & & & & & 0 & 3 & 0 & 3 \\
\hline & & 地区計画 & & & & & & $\mathrm{O}$ & 00 & 00 & & & & & & & $\mathrm{O}$ & & & & 0 & 5 & 1 & 6 \\
\hline & & 市街化調整区域 & & & & 00 & 00 & & & & & & & & & 0 & 00 & 00 & 00 & 00 & 4 & 1 & 8 & 13 \\
\hline 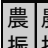 & & 農振農用地 & & & & 0 & & & & & & & & & & 0 & 00 & 00 & 00 & 00 & 1 & 1 & 8 & 10 \\
\hline $\begin{array}{l}\text { 振 } \\
\text { 运 }\end{array}$ & & 内非農用地 & & & & 0 & 00 & & & & & & & & & & & & & & 3 & 0 & 0 & 3 \\
\hline & 川条伍 & 例水源保全地域 & & & & 00 & 00 & & & & & & & & & & 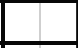 & & & & 4 & 0 & 0 & 4 \\
\hline & 之緑の & 刀景観づくり協定 & & & & 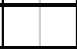 & H & & & & & & & & & & 0 & & & & 0 & 0 & 1 & 1 \\
\hline
\end{tabular}


民有林内の森林によって視覚的に遮られており、河川景観の構成要 素となっていない。また民有林には 1999 年 4 月より「恵庭市漁川流 域に係る水道水源の水質の保全に関する条例（以下、漁川水源条例）」 に基づく水道水源水質保全地域が指定され、特定用途に対して開発 時の届出及び住民説明会の開催を求めている注12)。

\section{4-2．都市景観ゾーンの現状}

都市景観ゾーンには 9 本の橋梁が架かり、1 シーンに平均 6.9 要素 が含まれている。ほぼ全てのシーンに戸建住宅が含まれている他、 集合住宅や他の橋梁といった様々な人工的要素が確認された。恵庭 市景観計画では景観上の課題として河川緑地・公園の維持管理や、 看板・屋外広告物のデザインを挙げており、いずれも河川景観を構 成する要素として複数のシーンに含まれている。土地利用規制は用 途地域ごとの基準が適用されている他、上流部には地区計画が決定 され、沿川の戸建住宅に適用されている。

\section{$4-3$. 農村景観ゾーンの現状}

農村景観ゾーンには 4 本の橋梁が架かり、1 シーンあたり平均 6.7 と、比較的多くの要素が含まれている。他の景観ゾーンでは全く見 られない農地や農業用施設、防風林がほぼ全てのシーンに含まれて おり、農村景観を特徴付けている。この内農業用施設は色彩や形態 の周辺に与える影響が景観上の課題とされている。土地利用規制は 農振農用地が広く決定されている他、一部の大規模な防風林は森林 法に基づく生活環境保安林に指定され、防風や景観の創出等に配慮 した施業の実施が定められている。また田園住宅地を目指す地区で は、花の田園住宅地区地区計画及び花と緑の景観づくり協定が運用 されている。全ての景観ゾーンの中で唯一、森林法・都市計画法・ 農振法に基づく土地利用規制が全て決定されている。

\section{5. 景観構成要素ごとの取組み}

表 3 を基に、河川景観を構成する様々な要素の中から出現頻度の 高い景観構成要素を抽出し分類した ${ }^{15)}$ 。1つ目に河川管理施設や人 工護岸、橋梁、サインといった「河川区域内工作物」であり、都市 景観ゾーンを中心に全ての景観ゾーンで確認された。2つ目に戸建 住宅や集合住宅といった「住宅建築」であり、農村景観ゾーンにお ける農家住宅の他、都市景観ゾーンのほぼ全シーンに含まれている。 3 つ目に沿川の公園や河川区域内の緑地、自転車道といった「公園・ 緑地」であり、都市景観ゾーンや農村景観ゾーンにおいて確認され ている。4つ目に「森林」であり、自然景観ゾーンの全シーンでみ られた。次節より河川景観を特徴付けると考えられる以上の要素ご とに対する取組みを示す。

\section{$5-1$. 河川区域内工作物}

多くの管理者が設置する河川区域内の施設では景観について考慮
されていないが、ダム管理者は「漁川ダム管理施設色彩ガイドライン」 を 2008 年 10 月より運用している。色彩の統一によるダムのトータ ルイメージコーディネートを目的とし、管理施設である取水塔や管 理事務所の他、周辺に民間事業者が設置する電波塔や自然景観ゾー ン以外に立地するサインも対象に含む事で、下流域を含めた良好な 景観形成に寄与している (図 5 )。他方で自然景観ゾーンで漁川と並 行寸る道道恵庭公園線は、2006 年 8 月策定の「支笏洞爺国立公園及 び周辺道路における道路付属物の色彩ガイドライン」対象路線となっ ている。北海道の地域特性を踏まえた色彩が専門家により検討され、 橋梁等に適用されている注 17)。都市景観ゾーンを中心に全ての景観 ゾーンで見られる人工護岸は、河川整備計画において堤防内の構造 物周辺及び安全性が損なわれるおそれのある区間で整備を実施する 事が示されている。漁川では主に低水護岸が景観構成要素として抽 出され、多自然型護岸として施工されている区間が広く存在する。 こうした護岸では河畔林の繁茂が護岸の一部を遮蔽しており、環境 に配慮した景観の創出に寄与している。その他、河川緑地整備事業 の実施区域付近では親水型護岸の施工がみられ、河川に近接可能な 親水空間を創出している。農村景観ゾーンではサケの遡上を阻害寸 る河川管理施設が設置されている課題を背景に、2000 年に魚道改修 工事が実施された。市が開発局に施設の改修を依頼し、開発局が「地 元関係者の意見を取り入れて改修の効果を上げたい」という要請を 行った事に基づき、複数回のワークショップ及びセミナーを経て改 修が進められた。整備の翌年からサケの遡上が確認された一方、構 造物の景観に関する議論は行われなかった ${ }^{\text {注18) }}$

\section{$5-2$. 住宅建築}

都市マスにおいて住宅地は地区計画の活用による環境整備が目指 されており、都市景観ゾーンの沿川には 2 つ地区計画が決定され ている ${ }^{\text {注 } 19)}$ 。地区計画ごとに細区分を設けており、建築用途の混在防 止を目的とした区分や高さ統一を目的とした区分等、それぞれ基準 が定められている。しかし全ての区分で形態意匠に関する言及や河 川に対する配慮といった項目はみられなかった。農村景観ゾーンの 花の田園住宅地区では地区計画の他、協定やガイドラインを活用す る事で形態の誘導が行われ、良好な住環境が担保されている。しか し地区計画の目標に漁川等の自然環境との調和を掲げているが、一 部しか河川景観の構成要素にはなっていない。

\section{$5-3$. 公園 · 緑地}

河川区域内の緑地整備について、河川整備計画では河川空間を出 来るだけ自然を活かした整備を行い、特に市街地では地域のまちづ くりと連携を図る事が目指されている。実際の整備事業では景観ゾー ンごとに異なる手法が用いられており、都市景観ゾーンでは主に国 土交通省等のモデル指定を受けて事業を実施している（図 6 )。例え
図 5 ダム管理者のガイドラインに基づくサインの改修前後注16)

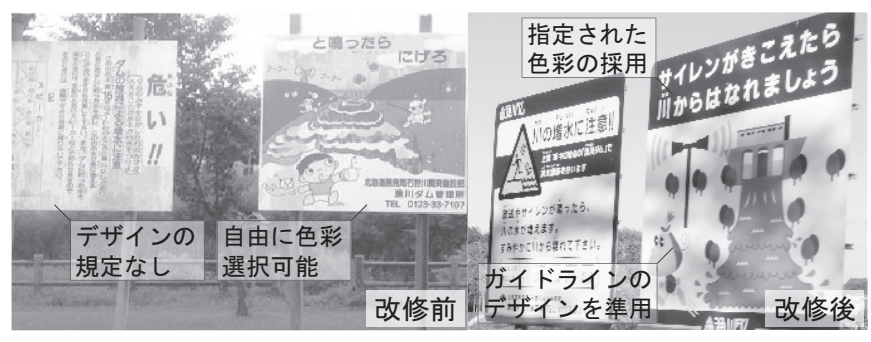

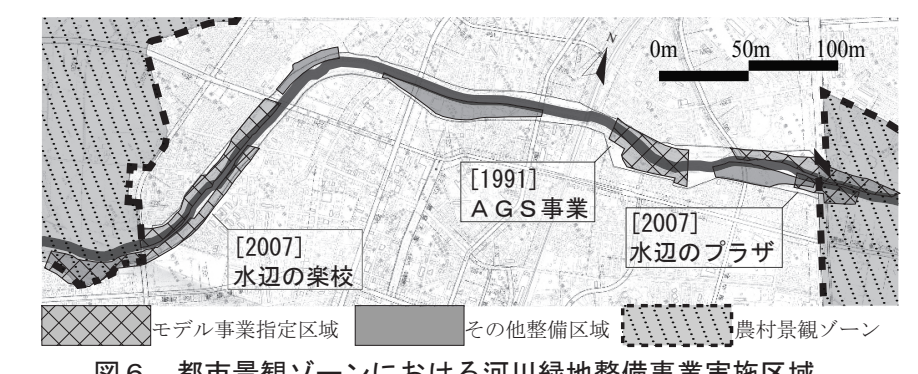

図 6 都市景観ゾーンにおける河川緑地整備事業実施区域 
ば水辺の楽校事業では 2002 年 1 月の指定後、市や小学校、住民団体 らで組織された協議会により浅瀬やイベント広場の設置が計画され た。こうした協議会の整備案を実施計画に反映する上で、国土交通 省のモデル指定を受けた事が整備の円滑化につながっている注20)。農 村景観ゾーンでは市が任意で 2001 年 3 月に策定した「都市・農村交 流ゾーン・交流拠点構想」に基づく緑地整備が行われている。本構 想は農村景観の節度ある活用を目的に、地区ごとの整備方針が示さ れている。その中の漁川が貫流寸る中央地区周辺交流エリアでは、 親水公園的な利用の促進として高規格パークゴルフ場の造成や、レ クリエーションルートの中継点として自転車道の整備推進を位置付 けた事で、農村景観ゾーン内の公園・緑地整備が進められた。

\section{$5-4$. 森林}

自然景観ゾーンで広くみられる森林は国有林と民有林に分けられ、 国有林は北海道森林管理局により策定された国有林施業実施計画に 基づく管理が行われている隼 21)。一方で民有林は法定計画で景観に配 慮した施業を位置づけているが、市が 2012 年 8 月に自然景観ゾーン を対象として実施した民有林現地調查により、大半の民有林が管理 放棄されている状況が明らかになっている注22)。市は現在、管理の促 進を目的に森林所有者による「森林経営計画」の策定を促す取組み を進めているが、策定率は全市で約 $0.2 \%$ と低調である。民有林の管 理放棄は景観の阻害の他、その後の皆伐による裸山化やごみ投棄増 加の要因として懸念されている注23)。

\section{6. 各景観ゾーンにおける住民活動の実態}

4 章の現状調查に基づき、 5 章では要素ごとの取組みについて行 政施策を中心に分析を行った。本章では河川とその周辺の環境や景 観の整備・維持管理に寄与する住民活動について調查し（表 4)、景 観ゾーンごとにまとめる。

\section{6-1. 自然景観ゾーンにおける住民活動}

自然景観ゾーンでは水源地域特有の活動がみられた。浄水場上流 部の産業廃棄物処分場建設計画に反対する市民を中心に組織された 漁川の水を守る会は、活動を通じ建設の中止及び継続的な水道水源 の保全へ向けた条例の制定を実現している。同団体は現在も、水源 地域のパトロール活動やゴミ拾いを定期的に実施している。またダ 厶湖周辺では NPO 法人水環境北海道を中心に恵庭市や河川愛護会等 により組織される慈しみフェスタ実行委員会が 2000 年より毎年慈し
みフェスタを開催している。委員会は恵庭市やダム管理者だけでな く森林管理局や北海道の後援を受けており、多数の住民団体・行政 組織が参画する場となっている。活動開始時から毎年継続的に事前 打ち合わせや事後の反省会を行ってきた事で組織間の連携を保つ場 として機能しており、複数の住民団体の活動を目的に応じて一元化 寸る等、流域の一体的な管理に寄与していると考えられる。また同 じく 2000 年には水環境北海道が水源地域における河川流域の荒廃地 を購入し、植林による河川環境復元を計画した。しかしながら土地 取得により生じる固定資産税の増加や NP0 による農地取得に関する 制度上の課題があり 注24)、現状の活動は他の団体も含め、水源地域の うち公有地内に制限されている注25)。

\section{6ー2. 都市景観ゾーンにおける住民活動}

都市景観ゾーンでは住民意見を踏まえた河川整備事業が実施され ているが、これは市が環境面のまちづくりに関する具体的指針とし て 2004 年 3 月に策定した「新・水と緑のやすらぎプラン」に基づき 進められている注26)。同プランでは計画から管理運営まで市民が主体 となる指針が組み込まれ、策定は NPO 法人水環境北海道に委託し、 市民 30 人のワークショップを踏まえて進められた。プランの方針に 基づき AGS 事業注 27$)$ や水辺の楽校事業実施の際、地元町内会や住民 団体から意見を聴取している。参加した漁川ラブリバー振興会は現 在、他の住民団体と合併して恵庭河川愛護会として、市から財政支 援を受け活動している。合併を通じて活動内容や範囲を拡大し、河 川環境に配慮した稚魚放流活動や遊歩道の花植え等を行っている。

\section{6-3. 農村景観ゾーンにおける住民活動}

農村景観ゾーンでは、農振計画で定められる「地域協㗢による農地・ 水・環境の保全管理」といら方針に基づき設置された農家らによる 環境保全会が景観形成活動を行っている。農村景観ゾーンを 4 地区 に区分し、保全会ごとに活動テーマを設定している。この内、フラワー ロードへの植栽や、ヒマワリやキカラシといった景観作物の作付け を活動項目に含めているのは島松・東恵庭の 2 つの保全会のみであ る。更に景観作物の作付けは、両保全会においても農家の協力に依 存している事から、面積の変動が大きい注28)。また魚道改修では、開 発局の要請を受けたえにわ市民サケの会がワークショップによる対 策案の検討を企画し、研究者等を含めて整備方法が議論された。サ ケの会は現在も稚魚の放流活動を継続的に実施している。更にワー クショップに参加した住民は整備に意見が反映された事の理解を通

表 4 各景観ゾーンで活動する住民団体 ${ }^{\text {注29) }}$

\begin{tabular}{|c|c|c|c|c|c|c|c|}
\hline 追坋项㖪 & \multicolumn{2}{|r|}{ 自然景観ゾーン } & \multicolumn{3}{|c|}{ 都市景観ゾーン } & \multicolumn{2}{|c|}{ 農村景観ゾーン } \\
\hline 団体名称 & 漁川の水を守る会 & 慈しみフエスタ実行 & NP0法人水環境北海道 & 辺の楽校推進協議会 & & えにわ市民サケの会 & 環境保全会 \\
\hline 動期間 & 1998-現在 & 在 & 1993-現在 & & & 1993-現在 & 2007-現在 \\
\hline 欻機 & $\begin{array}{l}\text { 水源地域での産廃処理 } \\
\text { 施設建設への反対運動 }\end{array}$ & $\begin{array}{l}\text { 水道水源のえに } \\
\text { 環境保全 }\end{array}$ & $\begin{array}{l}\text { 全国水環境交流会（全 } \\
\text { 国組織）の発足に呼応 }\end{array}$ & $\begin{array}{l}\text { 楽校」事業対象 } \\
\text { 指定 }\end{array}$ & 助団体の合 & $\begin{array}{l}\text { 商工会議所を中心に、 } \\
\text { サケを呼び戻す動き } \\
\end{array}$ & $\begin{array}{l}\text { 国として農地・水・環境 } \\
\text { 保全向上対策の支援 }\end{array}$ \\
\hline Eな活動 & \begin{tabular}{|l|} 
河川周辺のゴミ拾い \\
自然環境保護の周知 \\
水源地域パトロール \\
\end{tabular} & $\begin{array}{l}\text { えにわ湖慈しみフェスタ } \\
\text { (湖岸のゴミ拾い・植樹) }\end{array}$ & $\begin{array}{l}\text { 水環境保全·改善事業 } \\
\text { (イベントの主催や計画 } \\
\text { 策定の受託) }\end{array}$ & \begin{tabular}{|c|} 
水辺の楽校」計画検討 \\
(必要な施設や開催 \\
するイベントにつついて)
\end{tabular} & \begin{tabular}{|l} 
稚魚の放流 \\
河川パトロール \\
遊歩道の花植え
\end{tabular} & \begin{tabular}{|l} 
稚魚の放流 \\
遡上した保護 \\
魚道改修への参加 \\
\end{tabular} & $\begin{array}{l}\text { 景観作物の作付け } \\
\text { フラワーロードの整備 } \\
\text { 防風林の枝打ち } \\
\end{array}$ \\
\hline \multirow{8}{*}{$\begin{array}{l}\text { 主な行政 } \\
\text { との連携 } \\
\text { による } \\
\text { 取組み }\end{array}$} & \multirow{2}{*}{ 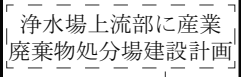 } & 市ダム森林 振興局 & \multirow[t]{2}{*}{ [水と緑のや-ーらぎプラン」 } & \multirow{2}{*}{$\mid$} & 開発局 & \multirow{3}{*}{ 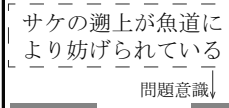 } & \multirow{2}{*}{$\begin{array}{l}\text { 農地·水保全管理支払 } \\
\text { 交付金事業(農振計画) }\end{array}$} \\
\hline & & 悛援 & & & & & \\
\hline & $\mid$\begin{tabular}{|l} 
反対 \\
\end{tabular} & \multirow{4}{*}{ 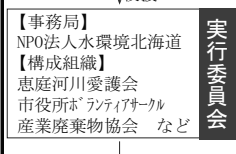 } & \multirow{2}{*}{ 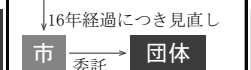 } & \multirow{2}{*}{$\begin{array}{l}\text { 【構成組織】 } \\
\text { 市 小学校 }\end{array}$} & 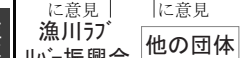 & & \\
\hline & 市 条例提案 団体 & & & & \multirow{2}{*}{ 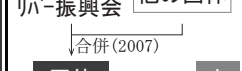 } & \multirow{2}{*}{\multicolumn{2}{|c|}{ 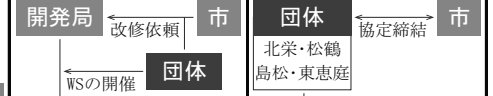 }} \\
\hline & 審議会に䜅問 板対運動 & & \multirow{2}{*}{ 住民 $\underset{\text { WS実施 }}{\longrightarrow}$} & $\begin{array}{l}\text { 町内会 } \\
\text { えに市民サケの会 議 }\end{array}$ & & & \\
\hline & & & & & 団体 䄧政支援 & & 保全会ご \\
\hline & \multirow{2}{*}{$\begin{array}{l}\text { 漁川水源 } \\
\text { 条例制定 }\end{array}$} & 企画 & 計画策定 & 整備案の提示 & 、区域·内容の桩大 & & \\
\hline & & 慈しみフェス夕の開催 & 新・水と緑のやすらぎプラ & 河川緑地整備の実施 & 河川関連活動の一元化 & 翌年からサケの遡上 & 2/4保全会が景観活動 \\
\hline 凡例 & 市 恵庭市 ダム 北海i & 支所 至 & 森林 北海入 & 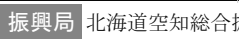 & & 団㑈 & \\
\hline
\end{tabular}


じ、その後も河川改修に対して積極的な意見の提示を行っている。

\section{7. まとめ}

以上の調査により明らかになった複数の土地利用を有する河川景 観の特性と課題についてまとめる。

（1）土地利用ごとの河川景観の特性

橋梁を視点場として河川景観の特性分析を行った結果、景観構成 要素の種類に地域間の差がみられた。森林地域では森林が他の要素 を遮蔽する効果を持っている事から景観構成要素の種類が少なく、 抽出される人工物は主に河川管理者の設置する工作物である。一方 都市・農業地域における景観構成要素の種類数は同程度だが、都市 地域では人工物が主な景観構成要素となっている。要素ごとに様々 な方策が講じられており、建築物については地区計画等の決定区域 であるか、橋梁については景観審議の対象となったかにより、景観 特性が決定付けられている。農業地域では農地・農業用施設・防風 林という他地域ではほぼみられない要素を中心に景観が構成されて いる。しかし農業地域内の河川は幅員が広く河畔林が繁茂している 事から、各要素の景観への影響は限定的である。

（2）法定計画ごとに位置付けられる景観施策の限定的な効果

土地利用に関する法定計画はそれぞれの目的や方針に応じ、景観 について記述される。森林計画では地域区分ごとの施業方法につい て景観を考慮して定めている。都市マスでは景観に関する方針の達 成に向け、土地利用規制と連動した開発の誘導を目指している。農 振計画では農村環境の保全に資する景観形成活動等を組織により取 組む事を位置付けている。しかし現状は、森林では適切な施業が行 われず管理が放棄され、個別の地区計画には景観の方針が継承され ておらず、農家らによる保全会は活動区域等が不安定である。つまり、 法定計画ごとに景観について考慮しているものの、いずれも実態に 与える効果は限定的である。

（３）管理者ごとに進められる河川区域内における景観への配慮

河川景観の主要構成要素である河川区域内の工作物は各地域に存 在し、様々な種類があり、複数の管理者により整備・管理されている。 こうした人工構造物について、河川整備計画はその整備に関する記 述を有する。一方で同計画は、人工構造物のデザインを河川景観に 馴染ませる事を方針に掲げているが、景観に配慮した構造物の設置 は一部に限られている。その内、色彩ガイドラインを運用する管理 者では、管理施設だけでなく周辺の電波塔等にも適用する事で、統 一した景観形成が進められていた。しかし同一地域に異なる目的を 持ったガイドラインが重複する場合や、橋梁に対してガイドライン の運用や委員会による審查と各地域で異なる対応を進める等、包括 的な視点はなく各管理者の自主性に依存している。

（4）住民による景観まちづくりの継続性と活動区域の制限

河川法や景観計画において、景観の維持管理を住民の役割として いるものの、参加の方法や手続きの有無は自治体や河川管理者に委 衫られている。住民意見を反映した河川整備の実施や条例制定、住 民団体を巻き込んだ計画策定は参加した団体の継続的な活動に寄与 している。しかし水源地域の保全を目的とした住民団体は活動区域 が公有地内に制限され、農業地域では半数の保全会のみが景観作物 の作付け等の景観に関する活動を行い、その区域も不安定であると いった課題が明らかになった。

\section{8. 考察}

以上の複数の土地利用を有する河川の景観特性と課題に対して、 良好な景観形成に資する方策を考察寸る。

基礎自治体が策定する土地利用ごとの法定計画の特性上、開発誘 導の視点を持つのは都市マスの計画区域に限定される事から、区域 外の開発行為に対する景観の視点は現行法定計画には位置付かない。 こうした状況に対し、土地利用区分に依らず行政区域全域を対象に 出来る景観計画を活用し、地域区分に応じた届出基準を設ける事が 考えられる。その際に森林計画の定める自然地域内の細区分や既存 の自主条例の届出基準を景観計画に取り込む事が望ましいと考える。

続いて、河川景観を構成する工作物に対してガイドラインの運用 が良好な景観形成に寄与している。しかし河川区域内の工作物には 多数の管理者が存在する事から、管理者ごとにガイドラインを策定 すると異なる目的を持つガイドラインが重複する事が考えられる。 その際に景観重要公共施設制度を活用し、基礎自治体と河川管理者 の連携による河川占用の許可基準を設定する事が望ましいと考える。 また、護岸や河川緑地など河川区域内の整備では、河川整備計画に 基づく治水・利水・環境に関わる指針が適用される。一方で護岸構 成や緑地の計画に当っては、周辺の土地利用や地域特性に応じて決 定する事が望ましいと考える。そこで基礎自治体は任意計画の策定 等を通じ、地域の要請に応じた整備を進める仕組みづくりを行う事 が望ましいと考える。

最後に、河川周辺では様々な目的を持った住民団体の活動が良好 な景観・環境の維持管理に寄与しているが、活動は民有地で行う事 が困難である。河川周辺の民有地も含めた良好な景観形成一向け、 景観法に基づく景観農振計画で農家による組織的な景観形成活動を 位置付け、安定的な活動の実施を支援する事が望ましい。更に管理 放棄された森林等を計画区域に含め、景観整備機構の指定を受けた $\mathrm{NP0}$ 法人等による民有地内の活動を促す事が望ましいと考える。また 花植え等の日常的な活動の他、河川工作物の改修や河川緑地の整備 に住民が関わる事で、事業における景観・環境への配慮を促す効果 がみられた。その際に国や広域自治体のモデル指定を受けて事業を 実施する事や、住民が専門家との協働を通じて、行政の計画や事業 に提案・要望する機会を増加させる事が望ましいと考える。

注

注 1）2013. 3 現在、11 道県において制定されている。

注 2）2013. 3 国土交通省の調查より、全 384 団体中 350 団体が全域を指定する。 注 3) $1 / 25,000$ 現況図に恵庭市における森林整備計画・都市計画図・農業地域 土地利用図・漁川水源条例指定区域を筆者が加筆したものである。

注 4) 2011 年 3 月策定「第 4 期恵庭市総合計画・後期基本計画」では 62 の目標 が設定されている。その 01 に「森林·農業·都市地域の地域特性に応じた土 地利用を図ります」、02に「恵庭らしい都市景観づくりを進めます」と定め ている。尚、森林地帯や農村地域の田園風景、街並みで都市景観が形成され ている、と説明されている事から、都市景観は都市全体の景観を指す。

注 5）北海道景観計画に基づく届出への勧告は、北海道が指定する主要な展望 地から地域の良好な景観資源が阻害されないか等の把握を通じ行われる。

注 6) 恵庭市では河川で活動する住民団体が 2002 年日本河川協会河川功労賞(え にわ市民サケの会) や 2005 年度北のまちづくり賞奨励賞 (NP0 法人水環境北 海道)、2010 年度日本ダム協会建設功労者表彰 (えにわ湖慈しみフェスタ実行 委員会）をそれぞれ受賞している。

注 7）漁川景観検討委員会は恵庭市水々緑のまちづくり審議会の外郭団体であ 
り、2000 年以降に黄金橋、あかね橋、中島橋、日の出橋の景観検討（橋の材質、 照明灯、高欄のデザイン、アーチ及び橋桁・歩道の色彩等）を行っている。

注 8）北海道屋外広告物条例では 6 種別の面積・高さ規定を設けている。都市 計画区域内は用途地域に従って比較的規制の緩い 1-3 種に適合し、市街化調 整区域や国道・道道から展望できる地域は 4 種となる。恵庭市の場合、都市 景観ゾーンは 1-3 種、自然・農業景観ゾーンは概ね 4 種が適用される。

注9) 調査対象橋梁は自動車と歩行者が通行可能な全ての道路橋としている。尚、 漁川ダムより上流部は近接不可能のため、調査対象区間は図 2 に示される漁 川ダムから千歳川との合流点までとした。

注 10）各シーン（橋梁から展望可能な範囲）に決定される森林法・都市計画法・ 農振法の基づく土地利用規制の把握を行った。

注 11）景観ゾーンごとに示される景観上の課題の内、阻害・検討項目に位置付 けられる要素を照らし合わせに用いた。また景観上の課題は、主に人工的要 素ではサインや施設の形態意匠、自然的要素では維持管理を位置づけている。 注 12）特定用途はゴルフ場及び廃棄物の最終処分場を指す。

注 13）パノラマ写真は 2014.7.13 に筆者が各橋梁の中心部の上・下流側から 視野角 $180^{\circ}$ で撮影したものを用い、土地利用図は図 1 と同様に作成した。

注 14）景観構成要素の名称について、他の橋梁」は視点場とした橋以外の橋梁、 「看板」は公共サイン、「電線」は視点場となる橋梁に架けられた電線、「その他」 は戸建・集合住宅以外の民間建築物（店舗等）、「農業用施設」は農業に与す る建築物としての施設 (農業用倉庫等)、「植林」は現地調査により確認され た住民団体等の植林活動区域をそれぞれ指す。

注 15) 20\% 以上のシーンで抽出された要素を出現頻度の高い景観構成要素とした。 注 16) 2014.10.16に北海道開発局漁川ダム管理支所へのヒアリングを実施。尚、 改修前の写真は北海道開発局提供資料より引用。

注 17）環境省で一般的に使用される色彩の適用ではなく、北海道の自然環境 に適した色彩の検討が環境省と学識経験者、北海道開発局により行われた。

注 18）2014.11.14 実施の流域生態研究所へのヒアリング及び 2000.11. 11 北海 道新聞朝刊「えにわ市民の会サケそ上できぬ漁川、魚道改修案提言へ」より。 注 19）図 1 内の左岸に美咲野地区、右岸に白樺地区地区計画が決定されている。 注 20）2005.5.25 総合計画審議会都市環境部会議事録より、河川管理者が水辺 の楽校登録地域では住民による整備案を許容する旨が発言されている。

注 21）計画では恵庭市内の国有林の主伐・間伐面積等が定められている。

注 22）2012.8.31 民有林現地確認会議録より、自然景観ゾーン内の現地調査を 行った結果、「一部下草刚り等の手入れをしているところはあるものの、放 置されている箇所が大部分」である事を確認している。

注 23）2014.9.2 実施、恵庭市経済部農政課へのヒアリングより。

注 24） 2000.3.30 北海道新聞朝刊「恵庭の NP0 荒れ地に緑再生を、土地購入し 植林を計画」より。

注 25）2014.11. 14 実施、流域生態研究所へのヒアリングより。

注 26） 1986.3 策定の「水と緑のやすらぎプラン」を見直したものである。

注 27）AGS（アクア・グリーン・ストラテジー）事業は北海道開発局の指定事業 であり、漁川では周辺住宅地や河川景観に配慮した改修が実施されている。

注 28）2つの保全会が行う景観作物（ひまわり・キカラシ）の作付面積は、 2012 年で $74 h a 、 2013$ 年で $134 h a 、 2014$ 年で 88 ha と変動が大きい。

注 29）参考文献 7）の事例報告に挙げられた恵庭市内の住民団体の内、漁川で 活動する団体及び 2003 年以降の団体合併・新設を考慮して作成した。尚、 作成に当たっては北海道新聞を中心とした文献の参照及び 2014. 1.24 実施の 恵庭市建設部管理課・2014.9.2 実施の恵庭市企画振興部まちづくり推進課 へのヒアリングを参考にしている。

\section{参考文献}

1）国土交通省河川局：河川景観の形成と保全の考え方,2006.10

2）国土交通省都市・地域整備局都市計画課: 逐条解説景観法, 景観法制研究会, 2004. 9

3）村川三郎, 西名大作, 植木雅浩 : 河川景観の画像特徵量と被験者注視点の 関連, 日本建築学会計画系論文集, No. 479, pp. 67-76, 1996.1
4）横山広充, 宮岸幸正 : 河川空間における初期眺望景観把握に関寸る研究 京都市内の河川空間からの眺望景観を対象として, 日本建築学会計画系論文 集, No. 683, pp. 115-122, 2013.1

5）木野健太, 佐藤雄哉, 松川寿也, 中出文平, 樋口秀 : 土地利用コントロー ルを視点とした景観計画の運用に関する研究, 日本都市計画学会学術研究論 文集, Vol. 49 No. 3， pp. 465-470，2014.10

6）小林昭裕 : 都市との交流を図る農村自治体における景観計画策定上の課題 北海道長沼町・当別町を事例に, 農村計画学会誌 29, pp. 251-256, 2010.11 7）荒関岩雄 : 水辺空間における住民・市民団体の活動事例 - 北海道恵庭市, RIVERFRONT, Vol.44, pp. 11-14. 2002 


\title{
A STUDY ON INITIATIVES AND COMMUNITY INVOLVEMENTS BY ANALYSING CHARACTERISTICS OF RIVERSIDE LANDSCAPES
}

Focus on the Izari river in Eniwa city flowing through a diverse landscape

\section{Takahiro YAMAZAKI* and Aya SAKAI**}

\author{
* Grad. Stud., Course of Architecture, Faculty of Engineering, Hokkaido University \\ ** Assoc. Prof., Course of Architecture, Faculty of Engineering, Hokkaido University
}

Typical rivers of Japan run through diverse landscapes including forests, urban lands and agricultural landscapes. After the revision of the River Act in 1997, the government aims to manage river with considering characteristics of riverside landscapes. On the other hand, the Landscape Act of 2004 was established with its purpose of developing good landscapes in not only urban areas but also rural areas. Therefore, riverside landscape should be formed with considerations on the status of measures adopted by plural sections.

Considering these facts, this paper reveals the characteristics of riverside landscapes by focusing on Izari River in Eniwa city flowing through a diverse landscape. And this paper examines methods on how to improve the riverside landscapes by using landscape measure adopted by plural sections.

This paper is based on bibliographic survey, field survey and resident's interview, and consists of following eight chapters, an introduction (Chapter 1), a body (Chapter 2 to 6), and a conclusion (Chapter 7 and 8).

In chapter 2 and 3, this paper focuses on Forest plan, City planning master plan, Agricultural development plan and Landscape plan formulated by Eniwa city, and reveals characteristics of these plans by analyzing a connection between the policy of landscape formation in Landscape plan and land use plan. Through this analysis, the following three points are clarified. First, Forest plan provides for the methods on how to maintain forest considering local scenery. Second, City planning master plan aims to develop good landscape with the action of regulating land use. Third, Agricultural development plan places organization working for landscape formation.

In chapter 4 , this paper clarifies the actual situation of riverside landscape in each zone by focusing panoramic photographs taken from all bridges over Izari River and land use maps such as forest planning map, city planning map and agricultural land use map. Through this survey, this paper clarifies that riverside landscapes consist mainly of river administration facilities, residential building, park and riverside open space and forest. In chapter 5, this paper focuses on above factors so as to reveal actual conditions and effects of landscape measure adopted by plural sections. Through this survey, it reveals that many administrators manage their river administration facilities and almost all of forests are not maintained.

In chapter 6, this paper analyzes the inhabitants' activities and reveals that they effects on maintenance of riverside landscape. In Forest zone, habitats pick up the garbage in order to conserve water resources. In Urban zone, neighborhood associations and local communities transmit their opinion when the government develops riverside open space. In Agricultural zone, farmers cultivate green manure crops for developing good landscape based on Agricultural development plan.

The following three points were clarified as the conclusion in Chapter 7.

1. The effect of land use plan formulated by several sections is limited.

2. A few administrators concern that their river administration facilities might spoil the scenery.

3. Habitats' activities for maintaining riverside landscapes are conducted especially in public space.

In chapter 8, this paper discusses methods of improving the riverside landscape such as applying the Landscape Act. 